Jpn. J. Limnol., 48, 4, 307-310, 1987.

Note

底泥中の銅の再溶出に及ぼす水中有機物の影響の銅 (II)

錯化容量による推定

内山征洋・赤岩英夫

\title{
Effects of Organic Materials in Water on the Desorption of Copper from Bottom Muds as Inferred from Copper (II) Complexing Capacity
}

\author{
Masahiro UCHIYAmA and Hideo AKAIWA
}

\begin{abstract}
There are numerous organic materials in natural water which might play an important role in desorbing metals from bottom muds. However, only a few materials, such as humic acid, EDTA and nitrilotriacetic acid have so far been studied. Some indices of organic materials which can remove metals from bottom muds are needed. In this report, copper (II) complexing capacity ( $\mathrm{CuCC}$ ) measured by the back extraction method was proposed as an index for evaluating the effect of organic materials on the desorption of metals from bottom muds.
\end{abstract}

Key words : Desorption of metals, Bottom muds, Copper (II) complexing capacity.

\section{1. 緒言}

底泥にいったん蓄積された重金属が再び水相へ移動 する要因としては，水流，攪はんなどによる底泥粒子 の水相への拡散に代表される物理的なもの，あるいは 底泥ないしは水相の雾囲気の変化による底泥からの溶 出のよらな化学的なもの, 更には, 生物を介して水相 への移動などが考えられるが，これらの要因が単独で 作用するのでなく相互に関連し合い，その機構はかな り複雑なものであろら。これらのうち，化学的な要因 に関する従来の報告をまとめたもの（日本水質污濁協 会，1985）によれば, ひ素に関し，底泥ないしは水相 の雾囲気の変化に伴う再溶出について比較的よく検討 されていることがわかる。化学的要因のらち, 水中に 存在する有機物の影響については, JACKSON and SKIPPEN（1978）は, フミン酸が底泥からの金属の再溶 出に影響を与えることを報告し，KosTAら（1978） は,トリポリリン酸およびEDTAの影響, また BANAT ら（1974）はニトリロ三酢酸の影響に関して実 験している。しかしながらこれらはいずれも, 特定の 試薬を用いた実験にすぎず，実際の環境中でおこる現 象からはかけ離れているといわざるを得ない。

ところで，環境水中の金属の溶存状態を検討する中
で，錯化容量の概念が導入されてきた（DAVY et al., 1973; SHUMAN and WOODWARD, 1973). 天然水の金属 錯化容量の測定法については, すでに総説がある (HART, 1981; NEUBECKer and Allen, 1983). 著者ら は，これまでに報告されている方法が，多数の試料水 を迅速に処理するには適当でないことを考慮し，簡便 かつ迅速に銅 (II) 錯化容量 ( CuCC) を測定し得る方 法として，キレート抽出系での逆抽出を利用する方法 を開発, 報告し, (AKAIWA et al., 1986; 赤岩ら, 投稿 中）天然水の $\mathrm{CuCC}$ の検討を行なってきた（内山ら， 投稿中)。

先に述べたよらに, 底泥中の重金属の水相への再溶 出に際しての水中有機物の影響に関しては, ある特定 の物質の影響をみるに止まっていた。これは一つには, 底泥中の重金属の水相への再溶出に関与する有機物は, 多種多様であると考えられるが，それを総合的に評価 しうる指標が見出せなかったことによるものと考えら れる。著者らは, CuCCが, このような指標に成り得 るものと考光，その可能性について検討を行なった。

\section{2. 実験方法}

2-1. 銅（II）錯化容量, CuCC の測定

ビス（ベンゾイルトリフルオロアセトナト）銅（II） 
$\left\{\mathrm{Cu}(\mathrm{bfa})_{2}\right\}$ による逆抽出法（AKAIWA et al., 1986）を 用いて測定した。概要は，次のとおりである。

ミリポア HA フィルター（孔径 $0.45 \mu \mathrm{m}$ ) でろ過し た試料水 $20.0 \mathrm{~cm}^{3}$ を $100 \mathrm{~cm}^{3}$ スキーブ形分液ロートに とり，これに, $5.00 \times 10^{-5} \mathrm{~mol} \cdot \mathrm{dm}^{-3} \mathrm{Cu}(\mathrm{bfa})_{2}$ のベン ゼン溶液 $20.0 \mathrm{~cm}^{3}$ を加えて 30 分間振り混ぜた。静置 して分相した後，水相を 5 C 万紙でろ過し，万液中の 銅（II）濃度を，原子吸光分析法により測定した。試水 の $\mathrm{CuCC}$ は

\section{$C u C C=$ 試水へ逆抽出された銅 $($ II ) 濃度}

と定義する。

\section{2-2. 底泥について}

底泥試料として，次の二種類を使用した。一つは， 渡良瀬川の上, 中, 下流において採取し風乾後, それ ぞれを同量ずつ混ぜ，ボールミルにて粉砕混合したも のであり，も5一つは，多摩川（丸子橋付近）の底泥 を渡良瀬川の底泥と同様に処理したものである。それ ぞれの底泥の銅の形態別の含有量を Table 1 に示し た。底泥重金属の抽出剤の相違による分別定量につい ては種々の方法があるが，ここでは，伊藤（1982）の 方法を参考にして，(1)イオン交換により溶解するもの

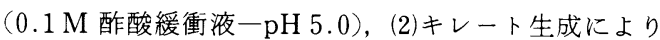
溶解するもの $\left(5 \times 10^{-2} \mathrm{M}\right.$ EDTA 溶液)，(3)酸により溶 解するもの $(0.1 \mathrm{M}$ 塩酸) の 3 種について測定した。

蓋つきのポリエチレン製遠心管に試料底泥 $3.0 \mathrm{~g}$ を とり, 各抽出剂 $50 \mathrm{~cm}^{3}$ を加え, 時々振り混ぜて $20^{\circ} \mathrm{C}$ で, 3 日間抽出した後, 遠心分離後, 上澄水中の銅濃 度を測定した。銅濃度の測定は, ジェチルジチオカル バミン酸ナトリウムーメチルイソブチルケトン（DDTC -MIBK）抽出後，原子吸光分析法で行なった。

\section{2-3. 抽出実験}

試料底泥 $3.0 \mathrm{~g} を 200 \mathrm{~cm}^{3}$ 蓋つきポリエチレン製遠

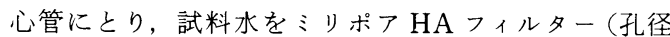
$0.45 \mu \mathrm{m}$ ）でろ過したろ液 $50 \mathrm{~cm}^{3}$ を加え，蓋をした 後, $20^{\circ} \mathrm{C}$ 恒温槽に入れ, 時々振り混ぜを行なった。一 定時間後，遠心分離を行ない，上澄中の銅濃度の測定 を行なった。銅濃度の測定は, DDTC-MIBK 抽出後, 原子吸光分析法で行なった。

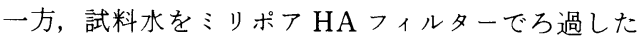
ろ液の一部をとり, 逆抽出法により $\mathrm{CuCC}$ の測定を行 なった。なお，抽出実験はすべて三回繰返し行なった
が，いずれも再現性は良好であった（変動係数： $1 \sim 5 \%$ )。

\section{3. 結果および考察}

Figure 1 に抽出時間と銅抽出量（3回繰返しの平均 值）の関係を示した。渡良瀬川および多摩川底泥につ いて，いずれも下水処理場の流入水を用いて抽出時間 の検討を行なった。ただし，両実験に用いた下水処理 場流入水は同一でなく，その CuCC は渡良瀬川底泥に よる実験の場合が $4.9 \mu \mathrm{mol} \cdot \mathrm{dm}^{-3}$ であり，多摩川底泥

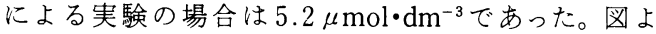
り,この条件においては, 短時間で銅の抽出量は平衡 に達し，抽出時間が 24 時間程度までは一定であり，以 後, 減少することがわかる。このことから，本実験に 打ける抽出時間を 24 時間とした。

Figure 2 は, $\mathrm{CuCC}$ の異なる種々の水を用いて，渡 良瀬川および多摩川の底泥からの銅の抽出量を検討し た結果である。

リン酸酸性一過硫酸カリウムにより 2 回蒸溜する方

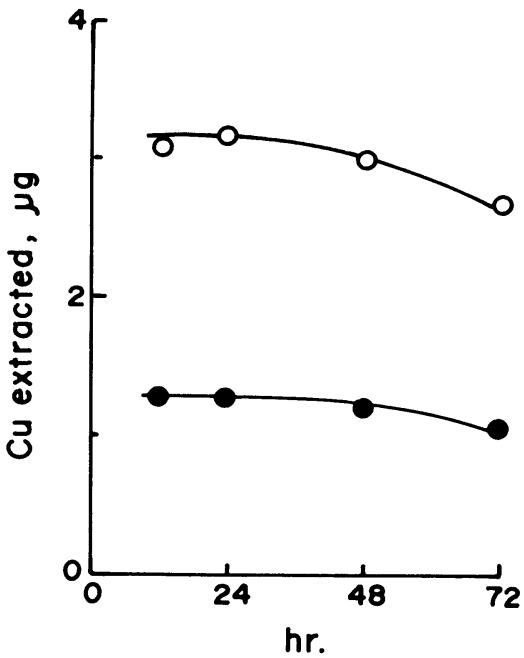

Fig. 1. The relationship between the extraction time and the amount of extracted copper.

$O$ : muds of Watarase River.

$\mathrm{CuCC}$ of the extracting water $4.9 \mu \mathrm{mol} \cdot \mathrm{dm}^{-3}$

- muds of Tama River

$\mathrm{CuCC}$ of the extracting water $5.2 \mu \mathrm{mol} \mathrm{dm}{ }^{-3}$

Table 1. Content of various forms of copper in bottom mud samples.

\begin{tabular}{lcccc}
\hline \multirow{2}{*}{$\begin{array}{c}\text { Leaching } \\
\text { solution }\end{array}$} & $\begin{array}{l}\text { Copper extracted, } \mu \mathrm{g} \cdot \mathrm{g}^{-1} \text { dry mud } \\
\text { acetate solution } \\
\text { (pH 5.0) }\end{array}$ & $\begin{array}{l}5 \times 10^{-2} \mathrm{M} \\
\text { EDTA solution } \\
(\mathrm{pH} \mathrm{4.8)}\end{array}$ & $\begin{array}{l}0.1 \mathrm{M} \mathrm{HCl} \\
(\mathrm{pH} \mathrm{1.0)}\end{array}$ & $\begin{array}{c}\text { Ignission loss } \\
(\%)\end{array}$ \\
\hline Watarase River & 0.48 & 35.8 & 54.3 & 1.5 \\
Tama River & 0.14 & 5.0 & 7.1 & 1.6 \\
\hline
\end{tabular}




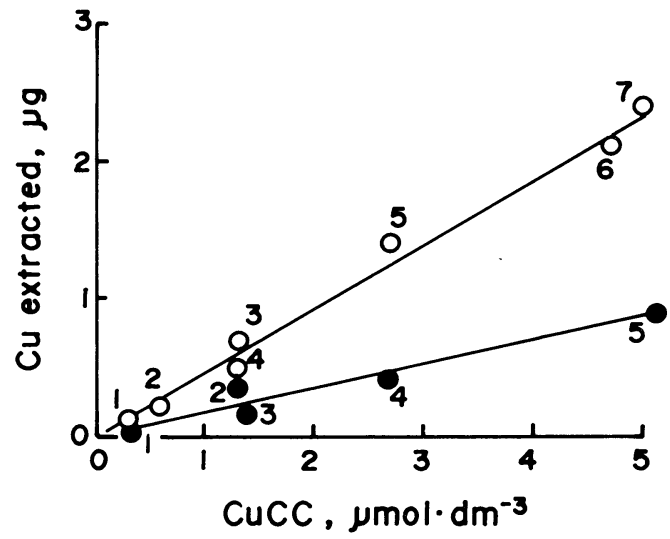

Fig. 2. The relationship between $\mathrm{CuCC}$ and the amount of extracted copper.

: muds of Watarase River

extracting water; 1 . sewage 2 . lake water 3. effluent of sewage treatment works 4. pond water 5. natural humic coloured water 6.7. influent of sewage treatment works

- : muds of Tama River

extracting water; 1. sewage 2. effluent of sewage treatment works 3. pond water 4 . natural humic coloured water 5 . influent of sewage treatment works

法（MENZEL and VACCARO, 1964）により作製した純水 $(\mathrm{CuCC}=0)$ を用いて，渡良瀬川および多摩川底泥の 抽出を行ない抽出された銅の量（それぞれ $0.8 \mu \mathrm{g}$ およ び $0.4 \mu \mathrm{g})$ を求め, 実際の水を用いての実験結果から この量を差引いた值を Figure 2 には示してある。四よ り, 各種試水の $\mathrm{CuCC}$ と抽出される銅との間には良好 な直線関係が認められた。渡良瀬川と多摩川とで, そ の抽出量がかなり異なるが，これは，Table 1 に示し たよらに，両底泥の銅含有量に差があることによるも のと考えられる。

緒言において述べたように, 底泥からの金属の再溶 出に及ぼす水中有機物の影響については，これまでに， いくつかの報告があるが，これらは，いずれも，単一 の有機化合物について実験されているにすぎなかった。 実験に用いられた，フミン酸，EDTA，ニトリロ三酢 酸, トリポリリン酸等は, これらが水中に存在する場 合は，底泥からの金属の再溶出に影響を与えるであろ う。しかしながらわれわれは，水中有機物の金属錯化 容量について種々検討する中で, 天然水中には金属と 錯体を形成し得るような有機物が多数あることを認め た。したがって，底泥からの金属再溶出に及ぼす溶存 有機物の影響を検討する場合，個々の有機化合物につ いて別々に行ならのでなく，影響を与える有機物を総 合的に評価し得る指標が必要となってくる。

今回は CuCC を指標としたため銅のみについて実験
を行なったが, CuCCが，このような指標に成り得る ことが示された。他の金属についても同様な結果が得 られるものと考兄れるが, さらに検討する必要があ る。

Table 1 から明らかなように, 今回使用した底泥は, いずれも，強熱減量が小さく，有機物含有量が低い試 料であった。したがって，水による金属の抽出操作に おいて，底泥から溶出される有機物はごく少ないと考 えられる。しかしながら, 有機物含有量の高い底泥の 場合は, 金属の溶出操作に際して, これら有機物が水 中へ溶出して金属の再溶出に影響を与える可能性があ り，これについては更に検討する必要がある。

\section{謝辞}

今回の実験に使用した多摩川底泥は神奈川県公害セ ンターの吉見 洋氏より提供していただいたものであ る。記して感謝いたします。

\section{摘 要}

底泥中の金属が水中へ再溶出する際の溶存有機物の 影響については，これまでに，いくつかの報告がなさ れているが，いずれも特定の物質について試薬を用い ての検討にすぎなかった。理由は，底泥中の金属の再 溶出に関与する有機物は多種多様であると考えられる が，それらを総合的に評価し得る指標が見出せなかっ たことによるものと考えられる。著者らは, CuCCが このような指標に成り得るものと考光検討を行ない良 好な結果を得た。

\section{文献}

Akaiwa, H., Kawamoto, H. and Ogura, H (1986): A new method for the measurement of copper (II) - complexing capacity of natural waters by back -extraction technique. Chem. Lett., : 605-608.

赤岩英夫, 川本博, 内山征洋 (投稿中): 2-テノイルト リフルオロアセトンを用いた銅 (II) 錯化容量の測 定法.

Banat, K., Forstner, U. and Muller, G. (1974): Experimental mobilization of metals from aquatic sediments by nitrilotriacetic acid. Chem. Geol., 14: 199-207.

Davey, E. W., Morgan, M. J. and Erickson, S. J. (1973): A biological measurement of copper complexation capacity of seawater. Limnol. Oceanogr., 18: 993-996.

HaRT, B. T. (1981): Trace metal complexing capacity of natural waters. Envir. Technol. Lett., 2 : 95-110.

伊藤和男 (1981): 河口域底泥中の金属の化学形に基づ く選択的溶解, 分析化学. 30:518-524.

Jackson, K. S. and Skippen, G. B. (1978): Geo- 
chemical dispersion of heavy metals via organic complexing: A laboratory study of copper, lead, zinc and nickel behaviour at a simulated sedi. ment-water boundary. J. Geochemical Exploration, 10: 117-138.

Kosta, L., Pihlar, B. and Dermelj, M (1978): Interactions of foreign substances in the environment. Trace Subst. Environ. Health. 12: 309316.

Menzel, D. W. and VAccaro, R. F. (1964): The measurement of dissolved organic and particulate carbon in seawater. Limnol. Oceanogr. 9: 138-147.

Neubecker, T. A. and Allen, H. E. (1983): The measurement of complexation capacity and conditional stability constants for ligands in natural waters. Water Res., $17: 1-14$.

日本水質污濁研究協会 (1984)：昭和 59 年度環境庁委 託業務結果報告書底質污濁改善対策調査一文献調

\section{査一}

Shuman, M. S. and Woodward, G. P. (1973): Chemical constants of metal complexes for a complexometric titration followed with anodic stripping voltammetry. Anal. Chem., 45 : 2032-2035.

内山征洋 - 中島 右 - 富沢恒夫 - 赤岩英夫 (1988)：榛 名湖の銅 (II) 錯化容量 (印刷中).

（著者：内山征洋, 群馬県衛生公害研究所, $\boldsymbol{\top} 371$ 前橋市岩神町 3-21-19; 赤岩英夫, 群馬大学工学部応 用化学科, $=376$ 桐生市天神町 1-5-1; Masahiro Uchiуama, Gunma Institute of Health Science and Environmental Science, Iwagami-cho, Maebashi, Gunma, 371, Japan; Hideo Akalwa, Department of Chemistry, Faculty of Technology, Gunma University, Kiryu 376, Gunma, Japan) 1987 年 10 月 13 日 受理 